\title{
How organisations generate and use customer insight
}

\author{
Emanuel Said ${ }^{1}$ (emanuel.said@um.edu.mt) \\ Emma K. Macdonald ${ }^{2,3}$ (emma.macdonald@ cranfield.ac.uk) \\ Hugh N. Wilson² (hugh.wilson@cranfield.ac.uk) \\ Javier Marcos² (javier.marcos@ cranfield.ac.uk) \\ 1. University of Malta, Msida MSD 2080, MALTA, \\ Tel: +3562340 2340 \\ 2. Cranfield School of Management, Cranfield University, Bedfordshire, MK43-0AL, UK, \\ Tel: $+44(0) 1234751122$ \\ 3. School of Marketing, City West Campus, University of South Australia, South Australia, 5001, AUSTRALIA, Tel: \\ $+61883020111$
}

\author{
Author for Correspondence: \\ Dr Emma K. Macdonald \\ Cranfield School of Management \\ Cranfield, Bedfordshire, MK43 0AL, UK \\ Tel.: + (0)7788 543 905, Email: emma.macdonald@cranfield.ac.uk
}

\section{Accepted to Journal of Marketing Management in March 2015}

\section{To cite this document:}

Said, E., Macdonald, E. K., Wilson, H. N., \& Marcos, J. (2015). How organisations generate and use customer insight. Journal of Marketing Management, 31(9-10), 1158-1179. doi:10.1080/0267257X.2015.1037785

\section{Acknowledgements:}

Emanuel Said was the recipient of the Academy of Marketing 2014 Conference Bursary. The authors gratefully acknowledge the anonymous managers who participated in this study and the anonymous reviewers of the Academy of Marketing 2014 Conference.

Published by Taylor \& Francis. This is the Author Accepted Manuscript. This article may be used for personal use only. The final published version is available online at DOI 10.1080/0267257X.2015.1037785. Please refer to any applicable publisher terms of use. 


\title{
How organisations generate and use customer insight
}

\begin{abstract}
The generation and use of customer insight in marketing decisions is poorly understood, partly due to difficulties in obtaining research access and partly because market based learning (MBL) theory views knowledge as a fixed asset. However, customer insight takes many forms, arrives at the organisation from increasingly diverse sources, and requires more than mere dissemination if it is to be useful. A multiple case study approach is used to explore managerial practices for insight generation and use. Multiple informants from each of four organisations in diverse sectors were interviewed. Findings reveal the importance of value alignment and value monitoring across the insight demand chain, to complement the information processing emphasis of extant research. Within the firm, the study suggests the importance of customer insight conduct practices including insight format, the role of automation, and insight shepherding, to complement the much-researched process perspective. The study provides a basis for assessing the effectiveness of insight processes by both practitioners and scholars.
\end{abstract}

Keywords: business to business marketing, customer insight, market based learning, market research, case study 


\section{Author biographies}

\section{Emanuel Said}

Emanuel Said is Lecturer in Marketing at the University of Malta. His research interests include customer insight, value-in-use and ethnography. He has presented at the UK Academy of Marketing Conference and the Australian New Zealand Marketing Academy Conference. Before embarking on his $\mathrm{PhD}$, Emanuel set up and subsequently sold a successful research firm in Malta.

\section{Emma K. Macdonald}

Dr Emma K. Macdonald is Senior Lecturer in Marketing at Cranfield School of Management and Research Director of the Cranfield Customer Management Forum. She is also Adjunct Research Fellow of the School of Marketing at the University of South Australia. Her research interests include customer experience, customer insight and customer value. She has published in Journal of Marketing Management, Journal of Retailing, Industrial Marketing Management, Journal of Business Research, Psychology and Marketing, and Harvard Business Review.

\section{Hugh N. Wilson}

Hugh N. Wilson is Professor of Strategic Marketing at Cranfield School of Management and Director of the Cranfield Customer Management Forum. His research interests include customer experience, marketing and sustainability, and multichannel customer management. He has published over 30 academic papers in journals including Journal of the Academy of Marketing Science, Harvard Business Review, Journal of Retailing, Journal of Business Research, Journal of Marketing Management and Industrial Marketing Management, amongst others.

\section{Javier Marcos}

Dr Javier Marcos is Senior Lecturer in Sales Performance at Cranfield School of Management. His main areas of expertise and research are selling and sales management, organisational learning and organisational development. Prior to joining Cranfield School of Management he worked for Unilever. 


\section{How organisations generate and use customer insight}

\section{Introduction}

A 2011 IBM study reported that $82 \%$ of marketing executives rely on customer insight for informed marketing decisions (IBM, 2011). This is consistent with the findings of the market orientation literature over the past two decades that reliance on customer insight is essential for optimising market offerings and associated returns (Kohli \& Jaworski, 1990; Narver \& Slater, 1990). Market-based organisational learning (MBL) is a subset of an organisation's overall organisational learning capability, and is an essential prerequisite for the achievement of a market orientation culture (Morgan, 2004). The increasing range of customer information sources available through a proliferation of media channels, together with more effective methods of data capture, are creating new challenges for generating customer insight from this information and managing its dissemination and use.

MBL literature has tended to conceive insight as being generated or acquired at a centralised point and then being distributed around an organisation (Cillo, De Luca, \& Troilo, 2010; Citrin, Lee, \& McCullough, 2007; Maltz \& Kohli, 1996). However, technology is disrupting these flows and changing the nature of customer insight. Despite the rapidly changing information environment and the related impact on volume of information flow into the organisation, there has been little academic research examining the implications for customer insight generation and use. Existing studies have tended to focus on the application of customer insight in marketing decisions (Maltz, Menon, \& Wilcox, 2006; Wei \& Wang, 2011) and given less consideration to the generation and management of customer insight. This may in part be because of the prevalence of single-informant studies which fail to capture the diversity of experiences of customer insight within an organisation (Cacciolatti \& Fearne, 2013; Korhonen-Sande, 2010). It may also be a consequence of the reliance on survey research which is limited in its capacity to capture the full range of managerial practices 
by which learning is enabled, particularly in a changing environment (Hodgkinson, Hughes, \& Hughes, 2012; Wei \& Wang, 2011).

This study investigates the generation and use of customer insight in organisations, firstly through a review of MBL literature and then through an empirical study with multiple informants in each of four case study organisations. We thereby make two primary contributions to literature on customer insight and market-based learning more broadly. First, we extend the previous understanding of customer insight strategy. We reveal in particular the importance of value alignment and monitoring across the insight demand chain of external providers and internal stakeholders. This is particularly relevant due to massive increases in data availability and the shift in expectations of clients of market research firms towards 'real time insight' (Macdonald, Wilson, \& Konus, 2012). Second, we clarify and enrich the understanding of the conduct of insight generation, to complement the extensive literature about the insight generation process. Specific dimensions of insight conduct include insight format, the role of automation, and complementary human practices in 'shepherding' insight around the organisation. Through rich qualitative data, we also shed light on how the insight generation process is enacted in practice.

\section{Insight generation and use}

Customer insight is typically conceived of as a strategic asset in MBL literature (Wills \& Webb, 2007), but its definition is often vague or absent. We follow Smith, Wilson \& Clark (2006) in defining customer insight as knowledge about the customer that is valuable for the firm. In turn, these authors draw on the resource-based view to argue that customer insight is a resource that is of value if it is rare, difficult to imitate and of potential use (Smith, Wilson \& Clark, 2006). Hence customer insight is distinct from customer information, as information requires transformation to generate insight (Smith, Wilson and Clark, 2006; Smith \& Raspin, 2008). Supporting this view of insight as a resource, customer insight is found to support the firm's response to environmental threats and opportunities and helps achieve customer-focused growth (Langford \& Schulz, 2006; Smith \& Raspin, 2008). 
MBL theory (Sinkula, Baker, \& Noordewier, 1997; Sinkula, 1994) tells us about the process of customer insight generation and application. At a broad level, customer insight involves exploration, as customer insight comes into the organisation or is generated within it, and exploitation as a result of deploying customer insight as a resource (Cyert \& March, 1963, 1992; Kim \& Atuahene-Gima, 2010). At a more detailed level, MBL theory conceives the customer insight process as four key stages of organisational learning about the customer (Table 1). The first involves identifying insight needs, and acquiring and where necessary transforming the needed market information, which may involve purchase from suppliers (Cacciolatti \& Fearne, 2013; Rapp, Agnihotri, Baker, \& Andzulis, 2014) and/or may require synthesis and analysis of customer, market and competitor information from different sources (Kohli \& Jaworski, 1990). The second involves the dissemination of this insight across the organisation (Cayla \& Arnould, 2013; Fang, Chang, Ou, \& Chou, 2014; Hughes, Le Bon, \& Rapp, 2012). The third concerns building a shared interpretation and agreed application of this interpretation in marketing decisions (Cayla \& Arnould, 2013; Moorman, 1995; Wills \& Williams, 2004). The final stage involves storage of insight into organisational memory (Perks, 2000; Smits \& Kok, 2012). This last stage has received little attention to date in MBL empirical studies, possibly because of the difficulty of gaining the necessary research access in order to track the formation and use of organisational memory. 


\section{Table 1: A review of empirical studies of market based organisational learning}

\begin{tabular}{|c|c|c|c|c|c|c|c|c|c|c|c|c|c|c|}
\hline \multirow{3}{*}{ Author/s (year) } & \multicolumn{5}{|c|}{ Study approach } & \multicolumn{9}{|c|}{ Study focus } \\
\hline & \multicolumn{3}{|c|}{ Method } & \multicolumn{2}{|c|}{$\begin{array}{c}\text { Unit of } \\
\text { analysis }\end{array}$} & \multirow[b]{2}{*}{$\begin{array}{l}\text { Insight } \\
\text { strategy }\end{array}$} & \multirow[b]{2}{*}{$\begin{array}{c}\text { Conduct of } \\
\text { insight } \\
\text { generation }\end{array}$} & \multicolumn{4}{|c|}{ Insight generation process } & \multicolumn{3}{|c|}{ Insight use } \\
\hline & 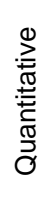 & 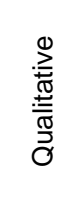 & 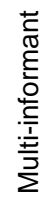 & 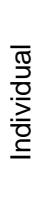 & 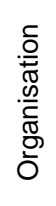 & & & 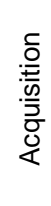 & 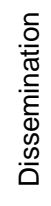 & 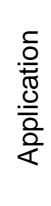 & $\begin{array}{l}\stackrel{\Phi}{8} \\
\frac{\pi}{0} \\
\text { ஸे }\end{array}$ & 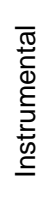 & $\begin{array}{l}\bar{\pi} \\
\stackrel{2}{0} \\
0 \\
0 \\
0 \\
0\end{array}$ & $\begin{array}{l}\frac{.0}{\bar{O}} \\
\text { है } \\
\text { की }\end{array}$ \\
\hline Deshpandé (1982) & $\mathrm{x}$ & & & $\mathrm{x}$ & & & & & $\mathrm{x}$ & $\mathrm{x}$ & & $\mathrm{x}$ & & \\
\hline Zaltman \& Moorman (1988) & & $x$ & $x$ & $x$ & & & $\mathrm{x}$ & $x$ & & $x$ & & & & \\
\hline Hill (1988) & & $x$ & & & & & & $x$ & & $x$ & & $x$ & & \\
\hline Kohli \& Jaworski (1990) & & $x$ & & & $x$ & & $x$ & $x$ & $x$ & $x$ & & $\mathrm{x}$ & $x$ & \\
\hline Sinkula (1990) & $\mathrm{x}$ & & & $\mathrm{x}$ & & & & $\mathrm{x}$ & $\mathrm{x}$ & $\mathrm{x}$ & & $\mathrm{x}$ & & \\
\hline Moorman, Deshpandé \& Zaltman (1993) & $\mathrm{x}$ & & & $\mathrm{x}$ & & $\mathrm{x}$ & $\mathrm{x}$ & $\mathrm{x}$ & & $\mathrm{x}$ & & $\mathrm{x}$ & & \\
\hline Moorman (1995) & $\mathrm{x}$ & & & & $\mathrm{x}$ & & $\mathrm{x}$ & $\mathrm{x}$ & $\mathrm{x}$ & $\mathrm{x}$ & & $\mathrm{x}$ & $\mathrm{x}$ & \\
\hline Diamantopoulos \& Horncastle (1997) & $\mathrm{x}$ & & & $\mathrm{x}$ & & & $\mathrm{x}$ & $\mathrm{x}$ & & $x$ & & $\mathrm{x}$ & $\mathrm{x}$ & \\
\hline Souchon \& Diamantopoulos (1997) & $\mathrm{x}$ & $\mathrm{x}$ & & $\mathrm{x}$ & & & $\mathrm{x}$ & $\mathrm{x}$ & & $x$ & & $\mathrm{x}$ & $\mathrm{x}$ & $\mathrm{x}$ \\
\hline Hurley \& Hult (1998) & $\mathrm{x}$ & & $\mathrm{x}$ & & $\mathrm{x}$ & & $\mathrm{x}$ & & & $\mathrm{x}$ & & & $\mathrm{x}$ & \\
\hline Perks (2000) & & $\mathrm{x}$ & $\mathrm{x}$ & & $\mathrm{x}$ & $\mathrm{x}$ & & $\mathrm{x}$ & $\mathrm{x}$ & $\mathrm{x}$ & $\mathrm{x}$ & & & \\
\hline Diamantopoulos \& Siguaw (2002) & $\mathrm{x}$ & & & $\mathrm{x}$ & & $\mathrm{x}$ & & & & $\mathrm{x}$ & & $\mathrm{x}$ & & \\
\hline Wills \& Williams (2004) & & $\mathrm{x}$ & $\mathrm{x}$ & & $\mathrm{x}$ & $\mathrm{x}$ & $\mathrm{x}$ & $\mathrm{x}$ & $\mathrm{x}$ & $\mathrm{x}$ & & $\mathrm{x}$ & $\mathrm{x}$ & \\
\hline Maltz, Menon \& Wilcox (2006) & $\mathrm{x}$ & & & & $\mathrm{x}$ & & $\mathrm{x}$ & $\mathrm{x}$ & $\mathrm{x}$ & $\mathrm{x}$ & & $x$ & $\mathrm{x}$ & \\
\hline Citrin, Lee, \& McCullough (2007) & $\mathrm{x}$ & & & & $\mathrm{x}$ & & & & & $x$ & $\mathrm{x}$ & $\mathrm{x}$ & $\mathrm{x}$ & \\
\hline Bailey, Baines, Wilson \& Clark (2009) & & $\mathrm{x}$ & $\mathrm{x}$ & & $\mathrm{x}$ & & $\mathrm{x}$ & $\mathrm{x}$ & & $\mathrm{x}$ & & $\mathrm{x}$ & $\mathrm{x}$ & \\
\hline Cillo, De Luca, \& Troilo (2010) & $\mathrm{x}$ & $\mathrm{x}$ & $\mathrm{x}$ & & $\mathrm{x}$ & & & $\mathrm{x}$ & $\mathrm{x}$ & $\mathrm{x}$ & & $\mathrm{x}$ & $\mathrm{x}$ & \\
\hline Korhonen-Sande (2010) & $\mathrm{x}$ & & & $\mathrm{x}$ & & $\mathrm{x}$ & & $\mathrm{x}$ & $\mathrm{x}$ & $\mathrm{x}$ & & $\mathrm{x}$ & $\mathrm{x}$ & \\
\hline Wei \& Wang (2011) & $\mathrm{x}$ & & $\mathrm{x}$ & & $\mathrm{x}$ & & & $\mathrm{x}$ & $\mathrm{x}$ & $\mathrm{x}$ & & $\mathrm{x}$ & $\mathrm{x}$ & \\
\hline Hodgkinson, Hughes, \& Hughes (2012) & $\mathrm{x}$ & & & & $\mathrm{x}$ & $\mathrm{x}$ & $x$ & $\mathrm{x}$ & $\mathrm{x}$ & $x$ & & & & \\
\hline Smits \& Kok (2012) & & $\mathrm{x}$ & $\mathrm{x}$ & & $\mathrm{x}$ & $\mathrm{x}$ & & $\mathrm{x}$ & $\mathrm{x}$ & $\mathrm{x}$ & $\mathrm{x}$ & & & \\
\hline Hughes, Le Bon, \& Rapp (2012) & $\mathrm{x}$ & & $\mathrm{x}$ & $\mathrm{x}$ & & & & $\mathrm{x}$ & $x$ & $\mathrm{x}$ & & $\mathrm{x}$ & $\mathrm{x}$ & \\
\hline Cayla \& Arnould (2013) & & $\mathrm{x}$ & $\mathrm{x}$ & $\mathrm{x}$ & & & & $\mathrm{x}$ & $\mathrm{x}$ & $\mathrm{x}$ & & $\mathrm{x}$ & $\mathrm{x}$ & \\
\hline Cacciolatti \& Fearne (2013) & $x$ & & & & $x$ & $x$ & & $\mathrm{x}$ & & $\mathrm{x}$ & & $\mathrm{x}$ & $\mathrm{x}$ & \\
\hline Rapp, Agnihotri, Baker, \& Andzulis (2014) & $\mathrm{x}$ & & $\mathrm{x}$ & $\mathrm{x}$ & & & & $x$ & & $x$ & & $x$ & $x$ & \\
\hline Fang, Chang, Ou, \& Chou (2014) & $\mathrm{x}$ & & & & $\mathrm{x}$ & & $\mathrm{x}$ & $\mathrm{x}$ & $\mathrm{x}$ & $\mathrm{x}$ & & & & \\
\hline Ihrig \& Macmillan (2015) & $x$ & $x$ & $\mathrm{x}$ & & $x$ & & & $x$ & $x$ & $\mathrm{x}$ & $x$ & & & \\
\hline This study & & $\mathbf{x}$ & $\mathbf{x}$ & $\mathbf{x}$ & $\mathbf{x}$ & $\mathbf{x}$ & $\mathbf{x}$ & $\mathbf{x}$ & $\mathbf{x}$ & $\mathbf{x}$ & $\mathbf{x}$ & $\mathbf{x}$ & $\mathbf{x}$ & $\mathbf{x}$ \\
\hline
\end{tabular}


From MBL research over the past four decades we know that use of customer insight is enabled or hindered by a number of factors, including the structure, systems and culture of insight use within the organisation (e.g. Deshpandé, 1982; Hodgkinson et al., 2012; Hurley \& Hult, 1998; Kohli \& Jaworski, 1990; Moorman, 1995). These factors we group into a category we call the conduct of insight generation. Organisational structure affects which individuals and departments are responsible for sourcing (Bailey, Baines, Wilson, \& Clark, 2009; Diamantopoulos \& Horncastle, 1997; Moorman, Zaltman, \& Deshpandé, 1992; Rapp et al., 2014), disseminating and storing insight (Fang et al., 2014; Korhonen-Sande, 2010; Moorman, 1995), while organisational systems affect the ease of communication and insight sharing across the organisation (Fang et al., 2014; Maltz et al., 2006; Sinkula, 1990). Organisational culture affects the format of customer insight sharing — for instance, whether insight sharing is technology-enabled or via face-to-face meetings (Maltz \& Kohli, 1996; Perks, 2000)_as well as the value attributed to customer insight (Diamantopoulos \& Siguaw, 2002) and the effort given to sourcing, sharing and acting upon it. Customer insight usage processes rely on interpersonal relationships within a social context (Moorman, Deshpandé, \& Zaltman, 1993; Smits \& Kok, 2012; Zaltman \& Moorman, 1988), and as such are subject to the impact of language and dialogue, and also have the potential for generating conflict (Lave \& Wenger, 1999; Nonaka \& Takeuchi, 1995).

Existing knowledge of insight processes and use comes from MBL studies conducted in a pre-Web 2.0 world. There is a pressing need for updated empirical research on the processes of customer insight use in a world of increasing computer power, where databases capture massive amounts of customer data, and where company and competitor information is democratized by social networks. The context of customer insight is an issue that has received limited attention in MBL literature, yet is a key source of tension for managers as the proliferation of channels and increased speed of information flow means that managers need to deal with customer insights in increasing volume and frequency (Hodgkinson et al., 2012; Souchon \& Diamantopoulos, 1997; Wills \& Williams, 2004; Zaltman \& Moorman, 1988). Additionally, recent improvements in CRM 
technology make internal sources of customer data more salient and the in-house versus agency trade-off an increasingly pressing challenge (Ryals \& Wilson, 2005). Previous studies have investigated customer insight strategy including the inter-organisational relationship between the client and external customer insight supplier (Diamantopoulos \& Siguaw, 2002; Moorman et al., 1992) and the purchasing of insight (Cacciolatti \& Fearne, 2103; Wills \& Williams, 2004), but few have explored the intra-organisational relationships between users of customer insight within an organisation (Hurley \& Hult, 1998; Korhonen-Sande, 2010; Maltz \& Kohli, 1996; Smits \& Kok, 2012). Those that have focused on the intra-organisational context have seldom looked at insight use beyond the marketing department (Perks, 2000; Smits \& Kok, 2012).

The MBL literature draws from organisational learning literature (Beyer \& Trice, 1982) to conceive three broad types of customer insight use, categorised according to the purpose to which the insight is put: instrumental, conceptual and symbolic. Instrumental use involves the use of insight in specific, direct ways to solve a particular dilemma that is relevant to an immediate opportunity (Diamantopoulos \& Souchon, 1996; Maltz \& Kohli, 1996; Maltz, et al., 2006). Conceptual use involves the exploitation of customer insight for general enlightenment, influencing choices and behaviours in more indirect ways than instrumental use without relatively immediate tangible action (Beyer \& Trice, 1982; Cillo et al., 2010; Maltz \& Kohli, 1996). Symbolic use involves users applying customer insight to justify and sustain previously held positions (Beyer \& Trice, 1982) including using insight to justify an action after reaching a decision (Diamantopoulos \& Souchon, 1996). This broad categorisation of insight use provides a starting point for assessing the impact and effectiveness of insight sources.

In summary, there is a need to re-examine customer insight generation in practice in today's digitally enabled environment. Particular areas requiring exploration include, first, how customer insight strategy plays out with the multiplicity of external and internal insight providers that has arisen through technology-driven insight innovations, and, second, the conduct of insight generation extending beyond the boundaries of the marketing function to users of insight throughout the firm. 


\section{Methodology}

In exploring how managers generate and use customer insight, a method is required that is sensitive to actors' interpretation of their social world (Easterby-Smith, Thorpe, \& Jackson, 2012). Managers structure their experience with customer insight in their minds through social processes (Schütz, 1962) within a socially-embedded context of practice (Brown \& Duguid, 1991). Because MBL theory is still evolving (Morgan, 2004), this study aims to generate provisional theory (Edmondson \& McManus, 2007) through content analysis and exploratory approaches. The case study method is adopted using an abductive strategy with the aim of understanding insight generation through managers' language, meaning and accounts in the context of everyday activities (after Blaikie, 2007). Operationalizing an abductive strategy requires case studies to be conducted sequentially, such that the first case study draws patterns from an initial analysis, and then the second case study checks and extends these within-case patterns, as well as allowing for exploration of variations across contexts. These tentative findings are carried forward to the third case study, and so on. This leads to the development of categories that are common to each case (Yin, 2009) with categories derived from iterations between data collection and analysis steps.

We selected case study organisations on the basis of the following criteria: (a) the organisations are involved in providing products or services in dynamic domestic markets where uncertainty is a key aspect to which firms respond by relying on customer insight; (b) they are medium to large organisations and have multiple users of customer insight located in different functions within the organisation (after Day, 1994; Slater \& Narver, 1995); and (c) they are organisations that rely on multiple information channels. We identified providers (typically an insight or market research function) and users of insight in each organisation and recruited multiple informants to participate in the study. Four organisations from diverse sectors in the UK were selected: a large international charity (Case1_CHAR), a communications company (Case2_COMM), an executive training organisation (Case3_TRAIN), and an information technology company (Case4_IT) (Table 2). 
Table 2: $\quad$ Sample description

\begin{tabular}{|c|c|c|c|c|c|c|c|}
\hline \multirow{2}{*}{ Organisation } & \multirow{2}{*}{ Sector } & \multirow{2}{*}{ Interviewee } & \multirow{2}{*}{$\begin{array}{l}\text { Management } \\
\text { level }\end{array}$} & \multirow{2}{*}{ Function } & \multicolumn{3}{|c|}{ Type of insight use } \\
\hline & & & & & Instrumental & Conceptual & Symbolic \\
\hline \multirow[t]{3}{*}{ Case1_CHAR } & Charity & CHAR1 & Senior & Insight & $x$ & $x$ & \\
\hline & & CHAR2 & Middle & Insight & $x$ & & $x$ \\
\hline & & CHAR3 & Middle & Insight & $x$ & $x$ & $x$ \\
\hline \multirow[t]{3}{*}{ Case2_COMM } & Telecommunications & COMM1 & Senior & Insight & $x$ & $x$ & \\
\hline & & COMM2 & Middle & Insight & $x$ & & \\
\hline & & сомМз & Middle & Insight & $x$ & & \\
\hline \multirow[t]{5}{*}{ Case3_TRAIN } & Training & TRAIN1 & Senior & NPD & $x$ & $x$ & $x$ \\
\hline & & TRAIN2 & Senior & Sales & $x$ & $x$ & $x$ \\
\hline & & TRAIN3 & Senior & Sales & $x$ & & \\
\hline & & TRAIN4 & Senior & Marketing & $x$ & & $x$ \\
\hline & & TRAIN5 & Senior & Marketing & $x$ & & $x$ \\
\hline \multirow[t]{5}{*}{ Case4_IT } & $\begin{array}{l}\text { Information } \\
\text { technology }\end{array}$ & IT1 & Middle & Marketing & $x$ & $x$ & \\
\hline & & IT2 & Senior & Marketing & $x$ & $x$ & $x$ \\
\hline & & IT3 & Senior & Sales & $x$ & & $x$ \\
\hline & & IT4 & Senior & Finance & $x$ & $x$ & \\
\hline & & IT5 & Senior & Sales & $\mathrm{x}$ & $\mathrm{x}$ & $x$ \\
\hline
\end{tabular}


We conducted individual depth interviews with managers within each of the four organisations. All interviews were digitally recorded and transcribed. We queried participants on their access to and use of insight and the main sources of insight. We investigated their use of customer insight as they engage in day-to-day activities with the intention of capturing "the meanings and interpretations, the motives and intentions, that people use in their everyday lives, and which direct their behaviour" (Blaikie, 2007, p90). We asked for descriptions of organisational structures (such as organisational charts) and the generation and use of insight across the organisation. Other data accessed included descriptions of internal systems, such as intranets, portals, repositories, and reports. In the case of the telecommunications organisation (Case 2) we were provided with temporary employee access to the internal research portal, and were able to fully explore it and analyse its usage statistics. The depth interviews with multiple informants as well as the access to company documents and systems provided a useful pool of data to enable investigation and triangulation of observations within each case study.

Using an abductive analysis approach means that our coding frame was evolved iteratively. We started data analysis by adopting an open coding approach of interview transcripts from the first case study (Charmaz, 2006; Corbin \& Strauss, 2008; Glaser \& Strauss, 1967) with a particular focus on managers' behaviours when engaging with customer insight. Our focus then moved to the customer insight as a learning process (Charmaz, 2006; Saldana, 2009), followed by a focus on explicit or implicit conditions impacting the users' engagement with customer insight. A focus on the ontology of the process (after Lam, 2000) ensued, followed by our last coding iteration focusing on managers' interactions with peers and associated stakeholders.

At each iteration of coding, our set of nodes grew from an initial small set to over 260 nodes. As a way of interpreting this multitude of nodes, we applied pattern coding (Miles \& Huberman, 1994) to combine nodes into more parsimonious themes. Informed by our earlier literature review, we began with two overarching themes: insight generation and use. Within 
insight generation, three major themes were insight generation process, conduct of insight generation, and insight strategy, again informed by the literature review above. Similarly, type of use had three major themes of instrumental, conceptual and symbolic use. While we allowed for the possibility that these major themes might need amending or supplementing in the light of the data, this eventuality did not arise. The lower-level themes shown in Figure 1 were, however, substantially derived from the data, albeit in iteration with the related literature we have discussed.

\section{Findings}

Figure 1 shows the resulting framework. Insight generation can be viewed as an organisational learning process of acquisition, dissemination, application and storage of insight. Complementing this perspective, however, this process is embedded into an organisation through a variety of practices such as the form insight takes, the nature of any automation for the insight process, and procedures for shepherding insight through the organisational learning process, which we term the conduct of insight generation. These conduct practices in turn relate to an overall albeit implicit - insight strategy. Through this combination of strategy, process and conduct, insight is applied to achieve instrumental, conceptual and symbolic purposes. We next describe these themes in more detail. 
Figure 1: Insight generation and use

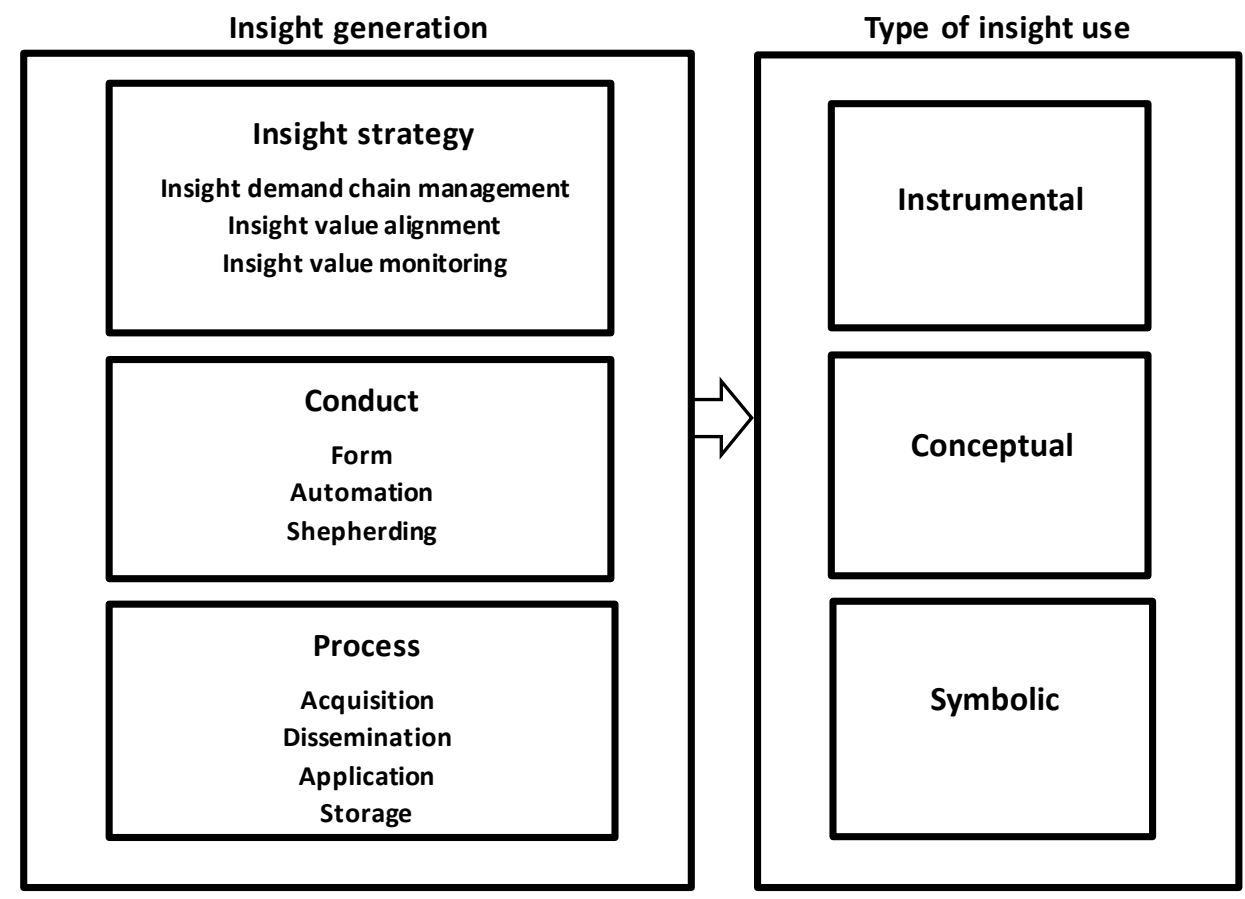




\section{Insight strategy}

Insight demand chain management: The MBL literature typically focuses attention on the capability of the organisation to acquire insight from external sources. Extending this literature (Bailey et al., 2009; Diamantopoulos \& Siguaw, 2002; Perks, 2000), the management of multiple external insight providers was a theme that cut across all case studies, as demonstrated in this quote from a senior insight manager in the charity organisation (Case 1): "We have got multiple agencies involved. So we've got the research agency, who obviously do the [ad hoc] research, but then we're evaluating the work of other creative agencies. So we have a branding agency. We have an online agency. We have our major line agency, who feed into the tracking....It needs a lot of back and forth to make sure it's right" (CHAR1). Findings indicate that firms rely on continual environmental scanning by employees, as well as on the acquisition of market research from different external suppliers (as in Wills \& Williams, 2004). This demand chain management process, then, involves the identification and contracting of external suppliers following an organisational buying processes, involving the market research function and insight users in specifically formed teams. Equally, however, this demand chain management extends to internal customers, as we illustrate below. The concept of insight demand chain management, then, adds to prior research on the importance of trust between external providers of market research and their internal clients (Zaltman \& Moorman, 1988), by encompassing both the wider business role of the market research function in managing a network of providers and the internal role of insight specialists in enabling the effective application of insight by their internal customers (KorhonenSande, 2010).

Insight value alignment: The market research department was identified as central in this demand chain management process, in particular having a crucial role in ensuring that outsourced market research is matched to business objectives, for instance as mentioned by the charity's (Case 1) senior insight manager: "Personally, I feel it's very important that all research projects, particularly when they're outsourced, are linked to the bigger business objectives. So that is the 
starting point... It's about sharing what we were doing, so that the agency could understand what we were trying to achieve, what we would be asking to evaluate and how we want our analysis reported" (CHAR1). In interviews, managers talked about how customer insight suppliers offer increasingly sophisticated solutions to their clients which, while interesting, make the job of acquiring external insight more challenging. The market research department also has a role in ensuring that customer insight is collected in an appropriate format and correctly understood by others in the organisation, as explained by the senior insight director in the charity (Case 1): "My team are very much the leaders of audience understanding. And that means all of the detailed expertise, in terms of what methodology is right; how to write good questions, questionnaires ... When working with [specific internal client] my team's job is to make sure that we're asking the question in the right way, collecting the right data, and reporting it back in the right way. He [internal client] owns the business question. We own the research question.” (CHAR1) While previous research has found that the organisations' formalisation and centralisation promotes efficient use of customer insight (Deshpandé \& Zaltman, 1982), our findings further suggest that the market research function - which may or may not be carried out by a specific named department strengthens the users' commitment to customer insight by facilitating their gaining a correct understanding from the insight and thereby actioning it. The market research function's credibility and skills promote users' commitment to insight use. In summary, the marketing research function acts to align what constitutes value to internal users with the capabilities of internal and external insight providers. This insight value alignment, then, goes beyond the information processing tasks of acquiring and disseminating market insight discussed in much previous literature (Sinkula, 1994; Ryals \& Wilson 2005); it equally includes focusing on the value required by internal customers of insight, and planning how best to assemble research supplier capabilities in order to create this value. This relates to the next topic of how the usage of insight to create value for the organisation can best be tracked. 
Insight value monitoring: In the MBL literature, only modest attention has been focused on how users across the organisation make use of customer insight (Cillo et al., 2010; Wei \& Wang, 2011). One emergent theme is that those who are responsible for sourcing and creating insight internally (typically the market research department) are often unsure about the impact of their research on organisational decision making and uncertain who is taking notice of the research, for instance a manager in the charity's (Case 1) research department observed that: "In my role, I'm less involved at the higher end of things, of influencing people and making sure that that happens...As far as I know, we do our best to make sure that all teams buy into the research process, and I think that's happening now, especially now ... a new division has been created, and has that mandate” (CHAR3). This suggests the need to monitor the use to which insight is put. In the telecommunications company (Case 2), where the market research department has set up a portal for sharing customer insight across the organisation, research specialists are able to conduct some monitoring on how widely an insight source might be reaching across the organisation. They do this through the measurement of insight report downloads and hence can see which reports are reaching departments across the organisation. However, even with the ability to track downloads and to identify users, a senior insight manager in the telecommunications organisation (Case 2) observed that there are still unanswered questions about the impact, longevity and amount of re-use of a single insight source: "a report might be downloaded by just one member in a department but then shared with ten others. It might then have a major impact in a key business decision" (COMM1). This suggests that a direction for future research might be to track insight around an organisation as it is shared between individuals and departments. Overall, the concept of insight value monitoring extends previous work on market research purchasing (Wills \& Williams, 2004) to emphasise internal information flows not just on how insight is disseminated but, crucially, on how it is actioned.

Without this insight monitoring, insight transformation and dissemination by insight specialists is to some extent a matter of guesswork. In the IT organisation (Case 4), an insight 
specialist reported on how he is involved in transforming research to solve specific insight requirements of internal customers, although the insight specialists do not necessarily see action taken as a result of that insight or know whether it is being used appropriately: "So someone will come to us with an issue and we will solve it for them using various sources. It doesn't mean I see it....we don't police how much they use it, if that makes sense." (IT3).

Managing external market research agencies, then, contributes to each of these themes of insight demand chain management, insight value alignment and insight value monitoring. Rather than being a straightforward purchasing process, a new product development manager in the executive training organisation (Case 3) observed that the relationship with external suppliers can rather become one of value co-creation: "So the next stage is to invite this one agency that we've selected out of the three to come back, to feel part of the team for the day, where we can actually tell them more about what we're trying to achieve, more about our marketplace and so they can get a greater buy-in - in terms of what it is that we really want. So at the moment we literally, all that really is happening, they have fed back one way with a few questions, but it would be great to get them to feel more as an extension to our team, and I think that would be the next stage of part of the process. Once that's happened we can then maybe re-check the brief and start to work through the mechanics of how it's going to be delivered and how quickly and how soon" (TRAIN1). The view of the relationship with an insight supplier is closer, then, to a value co-creation model than a traditional purchasing one (Payne et al., 2008).

\section{The conduct of insight generation}

Insight form: A theme cutting across several of the above examples is that providing customer insight in an accessible form is one way that organisations enable its effective use. As another example, within the charity organisation (Case 1), the research department collates several key insight sources into a comprehensive summary called a Fact Book. "It's a collection of everything we've learned about our different audiences from lots of different sources. ... We know a lot and have lots of data. This book is designed to sit on everyone's desk and to be a reference 
book. So all the brand tracking data gets put into the Fact Book twice a year, so everyone's got the most up to date brand footprint, attitudes to brand, attitudes to the issues we're working with, etcetera. " (CHAR1) This example illustrates that the concept of insight form extends beyond the information-processing issue of interpretation (Daft \& Weick, 1984; Smith \& Raspin, 2008) to also include challenges such as navigability and credibility.

Insight automation: With the similar intention of making insight accessible, in the telecommunications organisation (Case 2) the research department has created the previously mentioned portal in order to automate IT access, thus enabling anyone in the organisation to access market research reports. This portal includes documentation, statistics and interactive pages related to the organisation's markets, competition, products and customer segments. We conducted a detailed review of its structure and content. The structure included: information about general macro environmental developments; market and competitive intelligence; links to external insight providers; brand specific information; channel specific information; product specific information; customer segment information; and planned new products and business development. At the IT company (Case 4) it was apparent that in order to gain insight into customer journeys, such as the purchase journey from prospect to customer, it is necessary to manage and coordinate a wide number of data sources about the customer. This requires the organisation to have systems for data capture, which in the case of the IT organisation included several portals. Overall, the prominence of the theme of insight automation in our data appears to represent a change of emphasis as compared with earlier studies on insight dissemination (Moorman 1995; Maltz \& Kohli,1996), reflecting the multiplicity of insight sources available to contemporary organisations and the challenge of absorbing this insight.

Shepherding of insight: Coordination of insight needs across multiple internal stakeholders can be challenging and can lead to multiple interpretations of what is needed in a research brief. Managers might need to take a proactive role in managing these competing demands for insight as demonstrated in this quote from a manager at the training organisation (Case 3): "First of all there 
are many stakeholders - I think that is the important part...Some people have lots of conversations with our [stakeholders] ... and the direction and focus seems to be: 'I've just had a conversation with somebody last night who said we should be doing this and therefore let's do it'. [But] when you have many stakeholders, what you can't do is keep changing direction every few minutes that's unsustainable" (TRAIN1). We observe that the coordination of customer insight is a complex process, requiring the market research department to interact with managers from different management disciplines and roles, with obvious differences in communication styles and jargon. These differences pose challenges to the market research function, potentially hampering both the function's effectiveness in gathering insight from different sources and its ability to share insight with a profusion of managers across the organisation (Kohli \& Jaworski, 1990). Organisational structure here plays an important role as interdepartmental dynamics and connectedness influence a market research function's ability to effectively exchange insight with other functions in the organisation (Kohli \& Jaworski, 1990).

Effective exchange lies at the core of the insight department's role in shepherding customer insight sources through the organisation and getting insight to where it is needed. Not only does the insight department facilitate the sourcing of customer insight from external agencies but it pays careful attention to the format of the insight that is presented to others within the organisation, for instance in the executive training organisation (Case 3) those responsible for the insight function coordinate this insight as follows: "The actual delivery of this information can be given to us quite quickly. The way in which the delivery will be, will be a presentation to us, but more of a meeting. So it won't be 'here's the project, it's two hundred pages long - there you go - it's finished!'. They [external agency] could give us two, three hundred charts that might just sit on a dusty shelf and not be of relevance to anybody. People don't have the time to read that sort of information. I think what will happen is that they will come and present to us, tell us what they have and what we'd like further information on and then if we want to delve deeper in to various sections, they have the capability to do that for us." (TRAIN1) 
The insight department also plays a crucial role in interpretation of insight. For instance in the charity organisation (Case 1) the leader of the research department reflected on her role in highlighting interesting findings: "I mean on the projects I work on...I will say to [internal client], for example, "This is interesting” or "That's interesting" or "This is significant compared to something else”. So I would help highlight what they can refer to for the greatest impact" (CHAR3). Our observations highlight the importance of communication as a skill for the market research function (Hill, 1988) to effectively interpret insight for different users across the firm, employing both formal and informal approaches across the different audiences. Indeed at the IT company (Case 4) we observed members of the market research function discussing insight and associated marketing issues in both formal, equipped meeting rooms and across the range of informal spaces within the organisation. This range of discussions including informal mechanisms to help users to acquire the correct interpretation from insight (Kohli \& Jaworski, 1990) thereby enhancing the effectiveness of customer insight usage. Overall, the very human theme of shepherding of customer insight that emerges from our in-depth data complements the emphasis on the mechanics of information flows in much previous work (Hurley \& Hult, 1998; Kohli \& Jaworski, 1990; Bailey et al., 2009).

\section{The process of customer insight generation}

Our findings are consistent with the MBL literature (Baker \& Sinkula, 1999; Day, 1994; Sinkula et al., 1997; Slater \& Narver, 1995 among others) that customer insight generation is comprised of multiple stages, from acquisition, to dissemination, application, and storage. We find evidence of how the stages play out in practice through our data.

Customer insight takes a variety of forms (which is one of the reasons it is difficult to research). The following quote illustrates some of the ways that customer insight is transmitted from the research department around the organisation in the charity (Case 1): "Then there'll be an electronic version that is emailed down to our stakeholders. It's on our shared drive. It's on our monthly newsletter. And me, and my team, are open to going in and presenting that to any forum 
within the organisation. Any specific teams, within all of the divisions, might want to see it. So quite often we'll go and do the debriefing at team meetings or away day... to keep everyone up to date of what's been happening" (CHAR1). Overall, our observations are consistent with previous literature that acquisition and dissemination of insight involves both formal and informal interactions, where formal interactions are those that are organised, structured and verifiable by third parties while informal interactions involve interpersonal exchanges including causal and spontaneous conversations (Moorman, 1995; Maltz \& Kohli, 1996).

Customer insight is applied in identifying and qualifying business opportunities. The following quotation from the IT organisation (Case 4) illustrates how one source of customer insight is applied: “.... [it is] very high level and it also tells us about market shares... what share of the business space does our organisation have in the U.K... So, it at least gives us a direction as to the opportunity. We can compare that to the internal systems on what we are actually selling versus the size of the opportunity" (IT1). Customer insight is stored in a number of ways, as illustrated in the following quotation from an insight user in the IT organisation (Case 4): "We use an online tool called [named system] which is basically a... repository of account information. So, you put in an account name it brings up their turnover, it brings up their number of employees, it brings up their lines of business. We use that heavily to understand what industry segments to put people in" (IT3). Customer insight may result in cognitive, affective and behavioural changes in managers over the longer term (Cillo et. al, 2010). MBL literature has paid little attention to the storage of customer insight (Perks, 2000; Ryals \& Wilson, 2005), yet it is clearly important as stored insight may become a source of future customer insight.

From our interviews with multiple participants in each organisation it became apparent that while there are instances of all four stages of organisational learning, these stages do not necessarily occur in a linear way, nor do they occur within the domain of a single individual or even within a single department. Instead the content of customer insight emerges from a process involving the collaboration of multiple individuals both within and across departments. This process does not 
always run smoothly, for instance as illustrated in this quote from a research manager in the charity organisation (Case 1): “sometimes you'll get something which is maybe controversial, people can't agree on the interpretation of what they're hearing from the research. And sometimes that means that the point gets, some people think it's a really central point and some people discard it, so sometimes it leads to disagreement, which means that people can't agree on the outcome like what the research is really telling us...I have seen at least one piece of research where the same piece of information was interpreted in two totally different ways by different teams" (CHAR2). These findings contrast with the typical assumptions in MBL literature that customer insight is explicit and easily transferable between individuals (Diamantopoulos \& Souchon, 1996; Smits \& Kok, 2012).

\section{Conclusions}

Based on a synthetic literature review and a multi-informant, multiple-case study, this paper makes two broad contributions to literature on customer insight and, thereby, to market-based learning literature more broadly. The first is an extension to the previous understanding of customer insight strategy, in three respects. First, management of the insight demand chain goes beyond simple purchasing of insight (Diamantopoulos \& Siguaw, 2002) to encompass both competencies in managing the network of insight providers and, equally, the role of insight specialists in enabling the effective application of insight by internal insight users (KorhonenSande, 2010). Insight value alignment involves these specialists aligning the value required by internal customers with the competencies of external providers, adding a value dimension to the dominant information-processing view of market-based organisational learning (Sinkula, 1994). The related practice of insight value monitoring represents a virtually un-researched practice which, however, appears from our data to be crucial.

Second, we clarify and enrich our understanding of the conduct of insight generation, to complement the extensive literature about its process. Specific dimensions of conduct include 
insight form, the role of automation in insight dissemination, and the complementary role of insight specialists in 'shepherding' insight packets around the organisation. Our data suggest that in contemporary organisations, insight form is important not just for information-processing purposes such as aiding interpretation (Daft \& Weick, 1984; Smith \& Raspin, 2008) but also to address challenges such as navigability and avoiding information overload. Furthermore, insight form may play a role in insight credibility, relating to symbolic use as well as instrumental use of the insight. This echoes recent work on form and function in commercial relationships (Chitturi, Raghunathan \& Mahajan, 2007). Insight shepherding is particularly crucial in enabling instrumental benefits from insight; by contrast, conceptual applications of insight rely on users' direct engagement with multiple sources of insight, with or without automated enablement. The human-enabled shepherding theme complements the information-processing emphasis in much previous research on information flows (Kohli \& Jaworski, 1990; Smith \& Raspin, 2008), with or without the support of automation (Fang et al., 2014). Overall, our account of conduct demonstrates the interactions and behaviours that the market research function adopts in ensuring that users engage with customer insight most effectively, and is in contrast with the general propositions of existing MBL literature that is more concerned about measuring specific influences impacting on conduct (Kohli \& Jaworski, 1990; Hodgkinson et al., 2012; Rapp et al., 2014).

This study has several implications for practice. For external insight providers it suggests a number of mechanisms for lifting the perception of the agency from being one of many suppliers to 'a welcome member of the in-house team'. These include a co-creation philosophy with insight specialists in aligning research with anticipated use, and in aiding in the synthesis of multiple insight sources including from competitors. Insight providers can also beneficially look further along the demand chain to the research function's internal customers, not just to support dissemination of insight but to align the value these users require with insight form as well as insight content. 
For an organisation looking to translate customer insight into marketing action, this study illustrates some of the ways that this might be achieved successfully at each stage of the insight generation process. The findings are useful in reminding managers and team members that their colleagues are human beings, each with differing and multiple self-identities. This makes it more complicated when deciding how to understand the relevance of a particular research study or report with that individual. However, our emergent framework provides a starting point for redesigning processes within and beyond the firm to optimise not just insight generation and dissemination but insight use. Notably, as well as enabling efficient information flows through automation, insight specialists have a vital role in shepherding the insight through human contact, and in shaping the form of this insight and not just its content to match the intended use. More fundamentally, the need for value alignment suggests that insight generation can equally be viewed as a process in the opposite direction, starting with a deep understanding of the value requirements of insight users and matching this to capabilities of the demand chain. The creative tension between such a demand chain approach and the implicit production mentality of much market research practice, which seeks to commission market research and only then look for uses for it, is a topic which many practitioners are grappling with.

Future academic research should also apply a multi-informant approach as there are clearly differences in how the individual members of an organisation perceive customer insight. The findings from this study apply across case study organisations from several sectors; however, due to the small-scale qualitative nature of this study, further investigation is warranted. In addition, research that takes a longitudinal, quasi-ethnographic approach to tracking customer insight would be extremely helpful in further explaining some of the phenomena we have identified. A notable research direction is to unpack with more granularity the multiple uses to which our data suggests insight is put, to enrich the MBL literature's current typology of symbolic, instrumental and conceptual use. 


\section{References}

Bailey, C., Baines, P. R., Wilson, H. N., \& Clark, M. (2009). Segmentation and customer insight in contemporary services marketing practice: Why grouping customers is no longer enough. Journal of Marketing Management, 25(3/4), 227 - 252. doi:10.1362/026725709X429737

Baker, W. E., \& Sinkula, J. M. (1999). The synergistic effect of market orientation and learning orientation on organizational performance. Journal of the Academy of Marketing Science, 27(4), 411-427. doi: 10.1177/0092070399274002

Beyer, J. M., \& Trice, H. M. (1982). The utilization process: A conceptual framework and synthesis of empirical findings. Administrative Science Quarterly, 27(4), 591-622. doi:10.2307/2392533

Blaikie, N. (2007). Approaches to social enquiry: Advancing knowledge (2nd Edn., p. 243). Cambridge, UK: Polity Press.

Brown, J. S., \& Duguid, P. (1991). Organizational learning and communities-of-practice: Toward a unified view of working, learning, and innovating. Organization Science, 2(31), 40-57. doi: 10.1287/orsc.2.1.40

Cacciolatti, L. A., \& Fearne, A. (2013). Marketing intelligence in SMEs: Implications for the industry and policy makers. Marketing Intelligence \& Planning, 31(1), 4-26. doi:10.1108/02634501311292894

Cayla, J., \& Arnould, E. (2013). Ethnographic stories for market learning. Journal of Marketing, 77(4), 1-16. doi: 10.1509/jm.12.0471

Charmaz, K. (2006). Constructing grounded theory: A practical guide through qualitative analysis (pp. 1-224). London: Sage.

Chitturi, R., Raghunathan, R. \& Mahajan, V. (2007). Form versus function: How the intensities of specific emotions evoked in functional versus hedonic tradeoffs mediate product preferences. Journal of Marketing, 44(4), 702-714. doi: 10.1509/jmkr.44.4.702

Cillo, P., De Luca, L. M., \& Troilo, G. (2010). Market information approaches, product innovativeness, and firm performance: An empirical study in the fashion industry. Research Policy, 39(9), 1242-1252. doi:10.1016/j.respol.2010.06.004

Citrin, A. V., Lee, R. P., \& McCullough, J. (2007). Information use and new product outcomes: The contingent role of strategy type. Journal of Product Innovation Management, 24(3), 259-273. doi: 10.1111/j.1540-5885.2007.00249.x

Corbin, J. M., \& Strauss, A. L. (2008). Basics of qualitative research: Techniques and procedures for developing grounded theory (3rd Edn.). Thousand Oaks: Sage.

Cyert, R. M., \& March, J. G. (1963). A behavioral theory of the firm. Englewood Cliffs, N.J : Prentice-Hall.

Cyert, R. M., \& March, J. G. (1992). A behavioral theory of the firm (2nd Edn., pp. xii, 1-252). Blackwell Business. 
Daft, R. L., \& Weick, K. E. (1984). Toward a model of organizations as interpretation systems. The Academy of Management Review, 9(2), 284-296. doi: 10.5465/AMR.1984.4277657

Day, G. S. (1994). The capabilities of market-driven organizations. Journal of Marketing, 58(4), 37-52. doi: 10.2307/1251915

Deshpandé, R. (1982). The organizational context of market research use. Journal of Marketing, 46(4), 91-101. doi: 10.2307/1251365

Deshpandé, R., \& Zaltman, G. (1982). Factors affecting the use of market research information: A path analysis. Journal of Marketing Research, 19(1), 14-31. doi: 10.2307/3151527

Diamantopoulos, A., \& Horncastle, S. (1997). Use of export marketing research by industrial firms: An application and extension of Deshpande and Zaltman's model. International Business Review, 6(3), 245-270. doi: 10.1016/S0969-5931(97)00003-6

Diamantopoulos, A., \& Siguaw, J. A. (2002). The impact of research design characteristics on the evaluation and use of export marketing research: An empirical study. Journal of Marketing Management, 18(1), 73-104. doi: 10.1362/0267257022775936

Diamantopoulos, A., \& Souchon, A. L. (1996). Instrumental, conceptual and symbolic use of export information: An exploratory study of U.K. firms. Advances in International Marketing, 8 , $117-145$.

Easterby-Smith, M., Thorpe, R., \& Jackson, P. R. (2012). Management research (4th Edn). London, UK: Sage Publications Ltd.

Edmondson, A. C., \& McManus, S. E. (2007). Methodological fit in management field research. Academy of Management Review, 32(4), 1155-1179. doi: 10.5465/AMR.2007.26586086

Fang, S.-R., Chang, E., Ou, C.-C., \& Chou, C. (2014). Internal market orientation, market capabilities and learning orientation. European Journal of Marketing, 48(1/2), 170-192. doi: 10.1108/EJM-06-2010-0353

Glaser, B. G., \& Strauss, A. L. (1967). The discovery of grounded theory: Strategies for qualitative research (pp. 1 - 286). Piscataway, NJ: Aldine de Gruyter.

Hill, P. (1988). The market research contribution to new product failure and success. Journal of Marketing Management, 3(3), 269-277. doi: 10.1080/0267257X.1988.9964046

Hodgkinson, I. R., Hughes, P., \& Hughes, M. (2012). Re-examining the deployment of market orientation in the public leisure sector. Journal of Marketing Management, 28(11-12), 12491269. doi: 10.1080/0267257X.2011.645857

Hughes, D. E., Le Bon, J., \& Rapp, A. (2012). Gaining and leveraging customer-based competitive intelligence: The pivotal role of social capital and salesperson adaptive selling skills. Journal of the Academy of Marketing Science, 41(1), 91-110. doi:10.1007/s11747-012-0311-8

Hurley, R. F., \& Hult, G. T. M. (1998). Innovation, market orientation, and organizational learning: An integration and empirical examination. Journal of Marketing, 62(3), 42-54. doi:10.2307/1251742 
IBM. (2011). From stretched to strengthened: Insights from the global chief marketing officer study (p. 67). Somers, NY.

Ihrig, M., \& Macmillan, I. C. (2015). Managing your mission-critical knowledge. Harvard Business Review, 93(1/2), 80-87.

Kim, N., \& Atuahene-Gima, K. (2010). Using exploratory and exploitative market learning for new product development. Journal of Product Innovation Management, 27(4), 519-536. doi:10.1111/j.1540-5885.2010.00733.x

Kohli, A. K., \& Jaworski, B. J. (1990). Market orientation: The construct, research propositions, and managerial implications. Journal of Marketing, 54(2), 1-18. doi:10.2307/1251866

Korhonen-Sande, S. (2010). Micro-foundations of market orientation: Influencing non-marketing managers' customer information processing. Industrial Marketing Management, 39(4), 661671. doi:10.1016/j.indmarman.2009.06.006

Lam, A. (2000). Tacit knowledge, organizational learning and societal institutions: An integrated framework. Organization Studies, 21(3), 487-513. doi:10.1177/0170840600213001

Langford, R., \& Schulz, K. (2006). Gaining 3-D customer insight to drive profitable growth. Strategy \& Leadership, 34(2), 21-27. doi:10.1108/10878570610652608

Lave, J., \& Wenger, E. (1999). Learning and pedagogy in communities of practice. In J. Leach \& B. Moon (Eds.), Learners and Pedagogy (pp. 21 - 33). London: Sage.

Macdonald, E. K., Wilson, H. N., \& Konus, U. (2012). Better customer insight - in real time. Harvard Business Review, 90(9), 102-108.

Maltz, E., \& Kohli, A. K. (1996). Market intelligence dissemination across functional boundaries. Journal of Marketing Research, 33(1), 47-61. doi:10.2307/3152012

Maltz, E., Menon, A., \& Wilcox, J. B. (2006). The effects of flexible firm orientations on market information use: Intended and unintended consequences. Journal of Strategic Marketing, 14(2), 147-164. doi:10.1080/09652540600659780

Miles, M. B., \& Huberman, M. A. (1994). Qualitative data analysis: An expanded sourcebook (Second Edn., p. 338). London: Sage.

Moorman, C. (1995). Organizational market information processes: Cultural antecedents and new product outcomes. Journal of Marketing Research, 32(3), 318-335. doi:10.2307/3151984

Moorman, C., Deshpandé, R., \& Zaltman, G. (1993). Factors affecting trust in market research relationships. Journal of Marketing, 57(1), 81-101. doi:10.2307/1252059

Moorman, C., Zaltman, G., \& Deshpandé, R. (1992). Relationships between providers and users of market research: The dynamics of trust within and between organizations. Journal of Marketing Research, 29(3), 314-328. doi:10.2307/3172742

Morgan, R. E. (2004). Market-based organisational learning - Theoretical reflections and conceptual insights. Journal of Marketing Management, 20(1), 67-103.

doi:10.1362/026725704773041131 
Narver, J. C., \& Slater, S. F. (1990). The effect of a market orientation on business profitability. Journal of Marketing, 54(4), 20-35. doi:10.2307/1251757

Nonaka, I., \& Takeuchi, H. (1995). Knowledge-creating company. New York: Oxford University Press.

Payne, A., Storbacka, K. \& Frow, P. (2008). Managing the co-creation of value. Journal of the Academy of Marketing Science, 36(1), 83-96. doi:10.1007/s11747-007-0070-0

Perks, H. (2000). Marketing information exchange mechanisms in collaborative new product development: The influence of resource balance and competitiveness. Industrial Marketing Management, 29(2), 179 - 189. doi:10.1016/S0019-8501(99)00074-7

Rapp, A., Agnihotri, R., Baker, T. L., \& Andzulis, J. (2014). Competitive intelligence collection and use by sales and service representatives: How managers' recognition and autonomy moderate individual performance. Journal of the Academy of Marketing Science, 1 - 18. doi:10.1007/s11747-014-0384-7

Ryals, L., \& Wilson, H. N. (2005). Experimental methods in market research: From information to insight. International Journal of Market Research, 47(4), 347-367.

Saldana, J. (2009). The coding manual for qualitative researchers (pp. 1 - 224). London: Sage.

Schütz, A. (1962). Common-sense and scientific interpretation of human action. In H. L. van Breda \& M. A. Natanson (Eds.), Collected Papers I. The Problem of Social Reality (4th Edn., pp. 347). London: Springer.

Sinkula, J. M. (1990). Perceived characteristics, organizational factors, and the utilization of external market research suppliers. Journal of Business Research, 21(1), 1-17. doi:10.1016/0148-2963(90)90002-U

Sinkula, J. M. (1994). Market information processing and organizational learning. Journal of Marketing, 58(1), 35-45. doi:10.2307/1252249

Sinkula, J. M., Baker, W. E., \& Noordewier, T. (1997). A framework for market-based organizational learning: Linking values, knowledge, and behavior. Journal of the Academy of Marketing Science, 25(4), 305-318. doi:10.1177/0092070397254003

Slater, S. F., \& Narver, J. C. (1995). Market orientation and the learning organization. Journal of Marketing, 59(3), 63-74. doi: 10.2307/1252120

Smith, B., \& Raspin, P. G. (2008). Creating market insight - How firms create value from market understanding (p. 318). Chichester, UK: Wiley.

Smith, B., Wilson, H. N., \& Clark, M. (2006). Creating and using customer insight: 12 Rules of best practice. Journal of Medical Marketing, 6(2), 135-139. doi:10.1057/palgrave.jmm.5050013

Smits, A., \& Kok, R. (2012). The interplay between outbound team strategy and market information processing in the course of 'really new' NPD projects. Industrial Marketing Management, 41(5), 759-769. doi:10.1016/j.indmarman.2012.06.011 
Souchon, A. L., \& Diamantopoulos, A. (1997). Use and non-use of export information: Some preliminary insights into antecedents and impact on export performance. Journal of Marketing Management, 13(1-3), 135-151. doi:10.1080/0267257X.1997.9964463

Wei, Y. (Susan), \& Wang, Q. (2011). Making sense of a market information system for superior performance: The roles of organizational responsiveness and innovation strategy. Industrial Marketing Management, 40(2), 267-277. doi:10.1016/j.indmarman.2010.06.039

Wills, S., \& Webb, S. (2007). Measuring the value of insight - it can and must be done. International Journal of Market Research, 49(2), 155-166.

Wills, S., \& Williams, P. (2004). Insight as a strategic asset - the opportunity and the stark reality. International Journal of Market Research, 46(4), 393-410.

Yin, R. (2009). Case study research: Design \& methods (4th Edn., pp. i-xiv; 1-219). London: Sage. doi:8093792-8463001

Zaltman, G., \& Moorman, C. (1988). The importance of personal trust in the use of research. Journal of Advertising Research, 28(5), 16-24. 